\title{
写真撮影および分光分析の技術を用いた油彩画の科学調查法 Scientific Investigation Methods of Oil Paintings Based on Photographic and Spectrometric Techniques
}

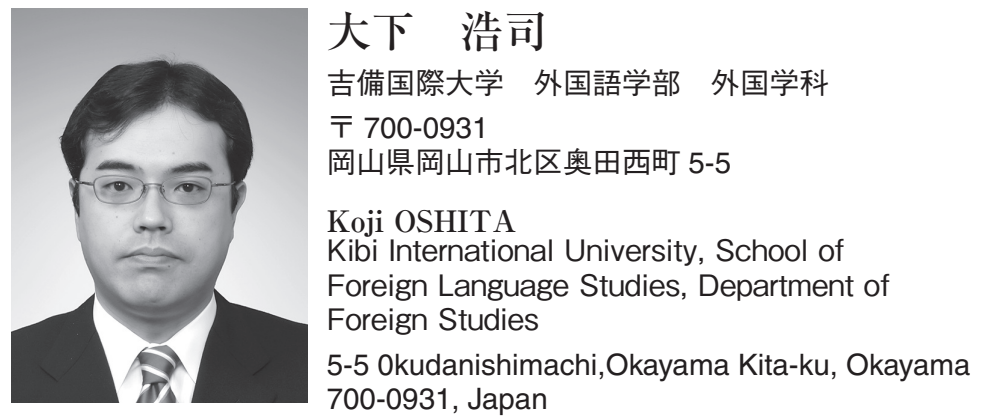

論文要旨 : 保存修復・技法解明・復元等のために油彩画の科学調査は非破壊かつ非接触で行なわれている。 赤外線写真・蛍光写真・X 線写真・斜光写真・顕微写真などの撮影技術および $\mathrm{X}$ 線・反射スペクトルなど の分光分析技術が油彩画の科学調査に用いられている。写真撮影は油彩画の状態や内部構造を観察するため に行なわれ，分光分析は油絵具の成分とその分布状態を測定するために行なわれている。これらの科学調査 技術は比較的早い段階で確立され実用に至っている。最近では新しい分析法やデータ解析法も開発・検討さ れている。このため本稿では従来の調査法に触れながら新たに開発・検討された調査法についても概説する。

\begin{abstract}
A scientific investigation on oil paintings is carried out nondestructively and noncontactly for conservation, elucidation of painting techniques and restoration of oil paintings. Photographic techniques such as infrared photograph, fluorograph, X-ray photograph, oblique lighting photograph and microphotograph, and also spectrometric techniques such as X-ray and reflection spectrum, are applied to the scientific investigation on oil paintings. Photograph techniques are done to observe the conditions and internal structures of oil paintings, also spectrometric techniques are performed to analyze the compositions and distributions of oil paints. These techniques of the scientific investigation have been established relatively early and are in practical use. Recently, novel scientific analysis methods and data analysis methods have been studied and developed. This paper describes the conventional and novel techniques reported for the scientific investigation.
\end{abstract}

Key words: oil painting, scientific investigation, photographic technique, spectrometric technique

\section{1 はじめに}

油彩画の科学調査では, 油絵具に含まれる顔料やレー キ顔料などの色材，絵画表面に塗られているワニス，修 復時に使用された材料などの各種絵画材料や油彩画の状 態を科学分析する。これらの絵画材料は書籍に詳しくま とめられており, 科学調査の際には参考にする ${ }^{1-3)}$ 。

この科学調査には, 赤外線写真·蛍光写真・X 線写真・ 斜光写真・顕微写真などの撮影技術, $X$ 線・ 反射スペク トルなどの分光分析の技術が主に用いられている。これ らの技術は, 油彩画に限らず日本画・浮世絵・染織品な

連絡者：大下 浩司

E-mail : oshita@kiui.ac.jp
どの文化財の科学調査にも広く使われている。文化財の 科学調査は, このような技術を用いて試料を採取するこ となく非破壊かつ非接触で行ない, 文化財に損傷を与え ることなく材料の劣化を抑え, 調査に関わる人と作品の 安全を確保し安心して行なえるよう十分に配慮してい る。

油彩画をはじめとする文化財の調査技術は比較的早い 段階で見出され実用に至っている ${ }^{4)}$ 。写真撮影や分光分 析の調査技術は書籍にも詳しくまとめられている ${ }^{5,6)}$ 。 このため本稿は, 既報の論文や書籍を参考にして油彩画 の科学調査に利用されている主な技術を取り上げ概説す る。最近では, 従来の調査技術に加え, 新しい分析法の 開発や測定データの解析法も検討されているため, これ 
らの試みについても触れる。

\section{2 写真撮影法}

油彩画の科学調査では, 赤外線写真・蛍光写真・X 線 写真・斜光写真・顕微写真を撮影する。これらの写真か ら油彩画表面の状態や内部構造を観察する。以下にこれ らの写真撮影法について記す。

\section{$2 \cdot 1$ 赤外線写真撮影法}

絵画表面の絵具層やその下層に使われた赤外線の光を 吸収しやすい色材の描写を観察するために, 油彩画の赤 外線写真を撮影する。この撮影には赤外線カメラを用い る。通常市販されているデジタルカメラには撮像素子の 前面に紫外線と赤外線をカットするフイルターが取り付 けられており赤外線写真を撮影できない。赤外線カメラ には赤外線をカットするフィルターはなく紫外線と可視 光線をカットするフィルターが付いている。もしくは, これらのフィルターが付いていない赤外線カメラの場 合, 油彩画に照射する赤外線の波長域や撮影条件に応じ てカメラのレンズ前面に赤外線のみが透過するフィル ターを適宜取り付け赤外線写真を撮影する。撮影は波長 800～1000 nm 程度の赤外線を油彩画に照射して行ない, 赤外線写真には油彩画の反射した赤外線が写る。赤外線 を反射しやすい部分は明るく，吸収しやすい部分は暗く 写る。赤外線の反射 ·吸収の強さは撮像部の相対的な明
暗の差から判断する。

赤外線写真に写った撮像は, 油絵具に含まれる色材の 種類や絵具層の厚さなどが関係している。赤外線は波長 が長く可視光線よりも物質を透過しやすいが，赤外線を 反射・吸収しやすい色材もある。このため, 各色材の標 準試料を調製し赤外線写真を撮影して撮像部の明暗を予 め調べておく。そして，後述の反射スペクトルも測定し 赤外線に対する色材の反射 · 吸収 ·透過の性質も調べて おけば, 赤外線写真の解析に役立つ。例えば, 赤外線を 反射しやすい白色下地のキャンバスに, 赤外線を吸収し やすい木炭を用いて下絵を描き，その上に油絵具で描い た絵画の赤外線写真を撮影すると次のようになる。

まず，絵画表面に塗られた油絵具に含まれる色材が赤 外線を 1）反射する場合，2）吸収する場合，3）透過す る場合に分けて考える。1）反射する場合は, 赤外線写 真には, 絵画表面の絵具層が明るく写り, 赤外線が表面 の絵具層を透過しないため下層に描かれた木炭の描写は 写らない。2）吸収する場合は, 絵画表面が暗く写り, 赤外線が絵具層を透過しないため下絵の描写は写らな い。そして 3）透過する場合は, 赤外線が表面の絵具層 を透過し下層まで到達するため, 木炭の描写が赤外線を 吸収し暗く, 描写のない白色下地部は赤外線を反射し明 るく写る。ただし, 絵具層に含まれる色材が赤外線を比 較的透過しやすい性質であっても，この絵具層が厚い場
(1) Cat Drawing

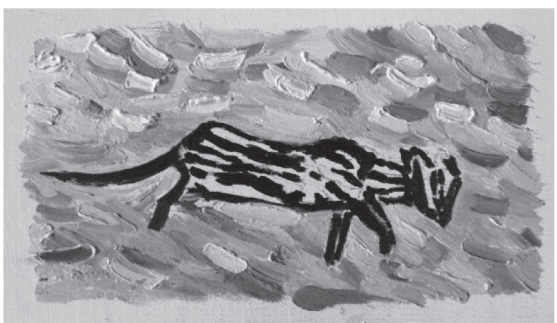

(3) Infrared Photograph

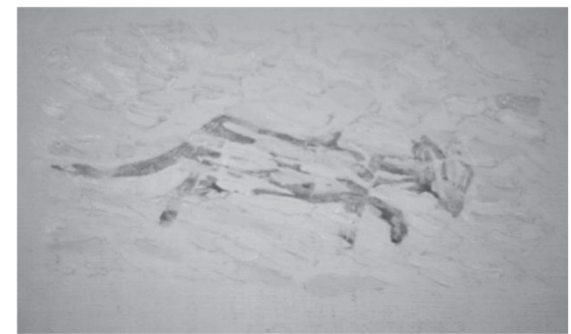

(2) Oil Painting Sample

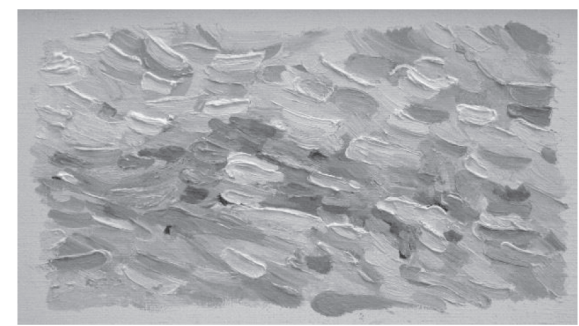

(4) Elemental Mapping

by X-Ray Fluorescence Analysis

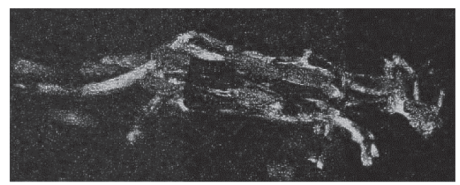

Fig. 1 Infrared Photograph and Elemental Mapping by X-Ray Fluorescence Analysis of Oil Painting Sample ${ }^{7)}$. 
合には赤外線を透過しにくくなるため，この厚みによっ ては赤外線写真で下絵を観察できないこともある。

油彩画試料（Fig. 1（2））の赤外線写真を Fig. 1（3） に示す ${ }^{7)}$ ここの油彩画試料は, 白色下地のキャンバスに 油絵具のプルシャンブルーを用いて猫を描き（Fig. 1 (1))，異なる種類の油絵具を使ってこの猫を塗り潰し ている（Fig. 1 (2))。この赤外線写真からプルシャンブ ルーで描いた猫の描写を確認できる（Fig. 1（3））。この ことから，油彩画試料に照射した赤外線が表面の絵具層 を透過して下層まで到達し, 白色下地は赤外線を反射し 明るく，プルシャンブルーの描写部は赤外線を吸収し暗 く写ったことがわかる。

\section{$2 \cdot 2$ 蛍光写真撮影法}

油彩画の表面に塗られたワニスの状態や蛍光性の色材 を含む油絵具の描写を観察するために蛍光写真を撮影す る。蛍光写真は紫外線を油彩画に当てその表面で発光す る可視光線の蛍光を撮影する。一般に市販されているデ ジタルカメラは，撮像素子前面に紫外線をカットする フィルターが付いているため，蛍光写真の撮影にも使用 できる。油彩画に照射した紫外線の光が写真に写る場合, カメラのレンズ前面に紫外線の光をカットするフィル ターを取り付ければ，可視光線の蛍光のみを撮影できる ようになる。撮影に用いる紫外線光源は, デジタルカメ ラには写りにくい極大発光波長 360～380 nm 程度のも のを用いると良い。紫外線写真の撮影時には部屋の照明 を消し暗くして行なうこともあるが，暗闇での撮影は人 や作品，機材などが転倒する恐れがある。このため，部 屋の明るさは事故を予防し安全に安心して調査を行なえ る程度の暗さに止め, いつでも照明を点灯して明るくで きるように工夫する。薄暗い程度であれば, カメラの絞 りを小さくし露光時間を短くするなどして調整すれば, 部屋の照明の微弱な可視光線は写真に写りにくくなるた
め，油彩画が発光した蛍光のみを撮影できるようなる。 しかし, 油彩画が発光する蛍光が弱い場合には, この蛍 光のみを撮影することが難しいこともある。このときは 無理をせず，部屋の照明の可視光線の光も写り込むこと を織り込んで蛍光写真を撮影し解析する。蛍光は紫外線 を強く受ければより強く発光するが, 紫外線は可視光線 よりもエネルギーが大きく長時間強く当てると油彩画の 劣化につながる。このため, 蛍光写真の撮影時には油彩 画に対し紫外線を長時間強く当て過ぎないよう心掛け る。

油彩画は，画面を保護したり艶を出したりするために 絵画表面にワニスを塗ることがある。画面に塗布され古 くなったワニスは蛍光しやすい。このことを利用して蛍 光写真からワニスの状態を観察する。ワニスが塗られて いれば蛍光し明るく，塗られていなければ蛍光せず暗い 撮像が得られる。画面の一部のみ暗くその周辺部が明る く写っていれば，何らかの理由によりその部分にワニス が無いか, もしくは絵具で加筆・修復・修整されたため その部分の表面にワニスが無いとも考えられる。ただし， ワニスの状態の観察は, 蛍光写真の撮像のみからは判別 の難しいこともある。このため, 絵画表面を目視してワ 二ス様の光沢の有無も確認する必要がある。ワニス以外 にも油彩画には蛍光性の色材を含む油絵具が使われてい る可能性もある。幾つかのレーキ顔料は蛍光することが 知られている。このような絵具も明るく写るため, 蛍光 写真からその描写を確認することができる。

Fig. 2 （2）には, ウッドワン美術館が所蔵するゴッホ 《農婦》の蛍光写真を示す ${ }^{8)}$ 。白色照明のもとで撮影し た通常写真（Fig. 2（1））では絵画表面に塗られたワニ スの状態を確認できないが, 蛍光写真 (Fig. 2（2））には, 絵画表面に塗布され古くなったワニスが蛍光し明るく 写っており，ワニスが塗られていることがわかる。そし
(1) Normal Photograph

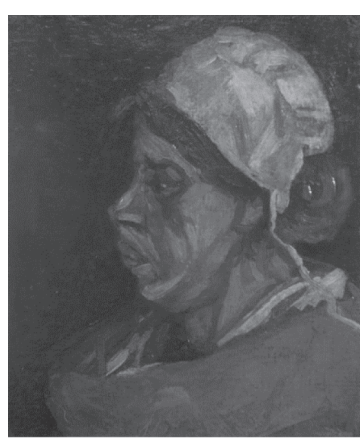

(2) Fluorescence Photograph

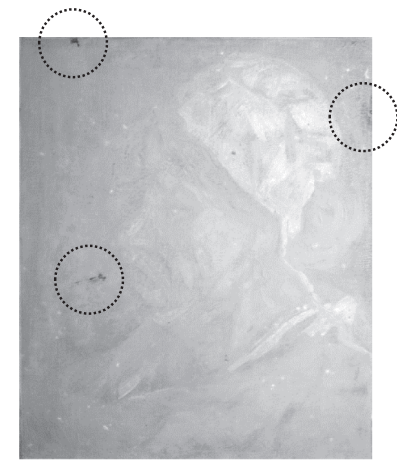

(3) X-Ray Photograph

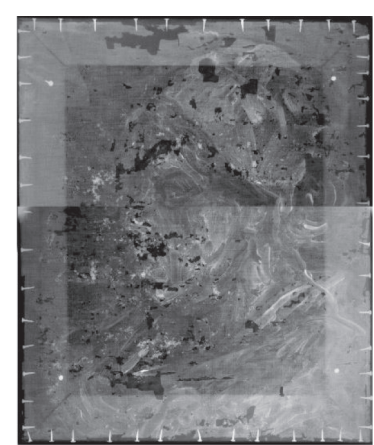

Fig. 2 Fluorescence Photograph and X-Ray Photograph* of Oil Painting ${ }^{8}$. ${ }^{*}$ The X-ray photograph has a border in the center of it because the upper and lower are taken and edited respectively. 
て，破線で囲んだ中央部分は暗く，この表面にはワニス が無い状態であることも確認できる。

\section{$2 \cdot 3$ X 線写真撮影法}

$\mathrm{X}$ 線写真は, 紫外線・可視光線・赤外線よりも波長の 短いX線という電磁波を油彩画に照射し, 透過したX 線を撮影する。この撮影には専用の装置を要する。X 線 写真は, X 線が透過しやすい部分は暗く, 透過しにくい 部分は明るく写るため, この撮像部の明暗から透過した $\mathrm{X}$ 線の強弱を判別して油彩画を構成する物質の密度・厚 み・内部構造を観察する。例えば, 物質の密度が低けれ ばX線は透過しやすく，高ければ透過しにくい。そして， 薄ければ透過しやすく，厚ければ透過しにくい。このよ うに密度や厚みが X 線の透過性に関係しているため, X 線写真に写った撮像部の明暗から油彩画の内部構造を観 察できる。

Fig. 2 (3) には, ゴッホ《農婦》の X 線写真を示す ${ }^{8)}$ 。 この作品は, 鉛白 $\left(2 \mathrm{PbCO}_{3} \cdot \mathrm{Pb}(\mathrm{OH})_{2}\right)$ を含むファンデー ションホワイトと亜鉛華 $(\mathrm{ZnO})$ を含むジンクホワイト でキャンバスの白色下地が塗られ，その上に油絵具を 使って農婦の姿が描かれている。制作後, 何らかの理由 によって絵具層と下地層が共に一部剥落し, 石膏 $\left(\mathrm{CaSO}_{4} \cdot 2 \mathrm{H}_{2} \mathrm{O}\right)$ などの材料を用いて充填し補彩されて いる。重い元素の鉛 $(\mathrm{Pb})$ や亜鉛 $(\mathrm{Zn})$ を含むオリジ ナルの白色下地部は X 線を透過しにくいため明るく白 みがかって写り，軽い元素のカルシウム（Ca）を含む 材料で充填された箇所はX 線を透過しやすく暗く黒み がかって写っている。このようにX線写真を撮影して 油彩画を観察すると，白色下地のオリジナル部と充填部 を判別できることもある。

《農婦》の木枠部に目を向けると，木枠と釷の形状も 確認できる（Fig. 2 (3)）。材料の密度と厚みの違いから $\mathrm{X}$ 線の透過性に差が生じたため, 明暗の異なる撮像が X 線写真に写っている。キャンバスの画布を木枠に固定す る釘は様々な形状のものがあるが，X線写真を撮影すれ ば表面から目視で判別できない釘の形状も確認できるよ うになる。

\section{$2 \cdot 4$ その他}

油彩画表面の状態を詳しく観察するために, 斜光写真 や顕微写真を撮影することがある。斜光写真は, 油彩画 表面に対し斜め前方から白色光を当て正面から撮影し， 撮像の院影から絵画表面の凹凸を観察する。絵画表面の 状態に応じて白色光の照射角度を変え，油彩画の側面あ たりから白色光を絵画表面に当て撮影することもある。 撮影には一般に市販されているデジタルカメラを使用す る。油彩画表面には油絵具の描写による凹凸があり，長 い年月が経つと絵具層の亀裂や剥落, キャンバス地のシ
ワ・波打ち・折れを生じることもある。肉眼でもこれら の凹凸をある程度まで確認できるが，斜光写真を撮影す ればより細かな凹凸も確認できるようになる。

顕微写真の撮影では, 絵具層の亀裂や剥離・剥落, 絵 具層の重なりや混ざり，微細な污れや変色などを観察す る。この撮影は実体顕微鏡にカメラを取り付け行なう。 アームが付いたタイプの実体顕微鏡を机上に設置すれば 大型サイズの油彩画でも隅々まで観察でき, 数倍〜数百 倍程度の顕微写真を撮影できる。最近では, レンズ周辺 部に配置されたLED ライトから被写体へ向けて白色光 を当て,レンズ部を被写体へ近づけオートフォーカスし, 数倍程度の顕微写真を撮影できるデジタルカメラも市販 されている。

\section{3 分光分析法}

前述の写真撮影法は油彩画の状態や内部構造の観察に 役立つが，油彩画の科学調査では，油絵具の色材成分を 同定したりその分布状態を調べることもある。ここでは, これらの調査に用いるX 線や反射スペクトルの分光分 析法について記す。

\section{$3 \cdot 1$ X 線分析法}

油彩画の科学調査には蛍光 $\mathrm{X}$ 線や X 線回折の分析法 が用いられる ${ }^{5,9)}$ 。油絵具に含まれる色材の成分元素の 同定は蛍光 $\mathrm{X}$ 線分析により行なわれる。蛍光 $\mathrm{X}$ 線分析 には元素のポイント分析 (測定点に存在する元素の分析) とマッピング分析（測定面内における元素分布の分析） がある。油絵具にX 線を当てると色材の成分元素がこ れを吸収し，元素に固有のエネルギー值をもった蛍光 $\mathrm{X}$ 線を発する。この蛍光 X 線のエネルギー值から色材の 成分元素を同定する。そして, 油絵具の色相と色材の成 分元素に対して検出された元素を照らし合わせ色材を判 別する。このとき, 絵画制作当時に流通していた油絵具 や画家が使用していた油絵具に関する文献情報なども収 集しておき参考にする。さらには，油絵具に含まれる顔 料と添加物の成分元素, 絵画表面の絵具層とキャンバス の下地に含まれる成分元素, 絵具を混ぜたり重ねたりし ている場合にはこれらに含まれる色材や添加物の成分元 素も蛍光 X 線分析により同時に検出される。このため, デー夕の解析は様々なことを踏まえて行なわなければな らない。最近では, 深さ方向の元素分布を測定できる蛍 光 $X$ 線分析装置も開発されている ${ }^{10)}$ 。本分析装置を用 いれば深さ方向に対する元素の分布状態が測れるため, 絵具が塗り重ねられた場合でも各絵具層に含まれる色材 の成分元素を分析できる。

このほかにも元素のマッピング分析を行なうことがあ る ${ }^{7}$ 11)。白色キャンバス地にプルシャンブルーを使って 
猫を描き，その上層に別の種類の油絵具でこの猫を塗り 潰した油彩画試料（Fig. 1（2））を元素マッピング分析 すると, Fig. 1 （4）のようにプルシャンブルー（化学式: $\left.\mathrm{Fe}_{4}\left[\mathrm{Fe}(\mathrm{CN})_{6}\right]_{3}\right)$ に含まれる $\mathrm{Fe}$ (鉄元素) が猫の描写 に沿って検出された ${ }^{7)}$ 。元素のポイント分析ではこのよ うな猫の描写を調査することは難しいが，マッピング分 析では可能である。しかしながら, 蛍光 X 線分析では, 色材の成分元素を検出するのみであり化学構造を解析す ることはできないため, 色材の判別には至らないことも ある。このときはX線回折分析や反射スペクトル分析 も合わせて行ない調査する。

$\mathrm{X}$ 線回折分析は, 結晶格子で $\mathrm{X}$ 線が回折される現象 を利用して結晶構造を解析する。物質に照射された X 線はその物質を透過する際に結晶構造に応じて回折され る。X 線が回折された角度と強度を測定すれば物質の結 晶構造がわかる。油絵具の $X$ 線回折分析では, 標準試 料として用意した既知の各種色材の回折角度と強度を予 め測定しておき未知の色材を測定したデータと比較し て，油絵具に含まれる色材の種類を同定する。

\section{$3 \cdot 2$ 反射スペクトル分析法}

光ファイバーの付いた分光光度計を用いれば，大型の 油彩画でも任意の測定点に扔ける反射スペクトルを非破 壊・非接触で測定でき, 光源と検出器の種類に応じて紫 外線 - 可視光線 - 赤外線の光に対する油絵具の反射スぺ クトルを測定できる。反射スペクトルは当該波長の光に 対する反射率の曲線で示される。例えば，可視光線の反 射スペクトルは油絵具の色相・明度・彩度が関係してお り，反射率の高い波長域が物質の色相を示し，この波長 域の反射率の高さが明度, 反射率の高い波長域と低い波 長域の反射率の差が彩度を表す。青色は $450 \mathrm{~nm}$ 付近, 緑色は $550 \mathrm{~nm}$ 付近に極大反射波長があり，黄色は $500 \mathrm{~nm}$ 辺りから長波長にかけて反射率が高くなり，赤 色は $600 \mathrm{~nm}$ 辺りから長波長にかけて反射率が高い。蛍 光しやすい油絵具では, この蛍光も反射スペクトルに反 映されることがある。

反射スペクトルの形状は物質の化学構造や組成が関係 している。しかし, 物質相互の反射スペクトル形状の差 は小さく，この形状から油絵具に含まれる色材の種類を 判別することは難しいこともある。このため, 反射スペ クトルの解析法を検討した試みが報告されている。まず, 反射スペクトルの二次微分解析では, 反射スペクトルの 形状が類似し反射と吸収が弱くピーク幅が狭くとも，二 次微分解析することにより色材の化学構造や組成に由来 する強くシャープなシグナルが得られる ${ }^{12)}$ 。二次微分の ほかにも反射スペクトルを多変量解析して異なる 3 種の 色材を含む白色油絵具を判別しようとした試みもある ${ }^{13)}$ 。

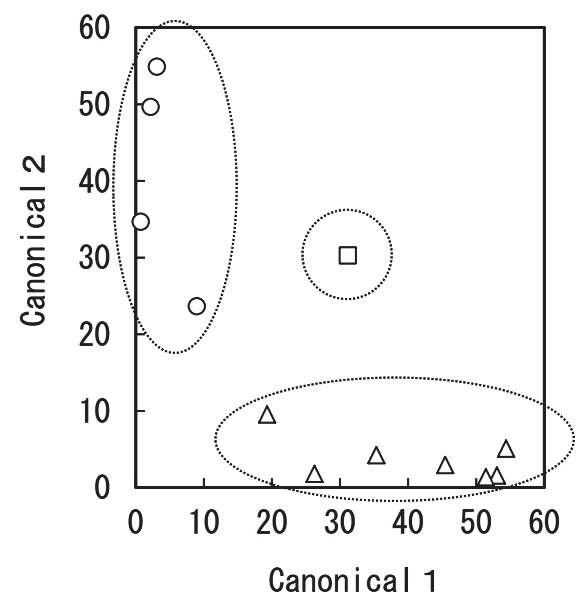

Fig. 3 Discriminant Analysis of White Oil Paints Containing White Lead $(\bigcirc)$, Zinc White $(\triangle)$, Titanium White $(\square)^{13)}$.

多変量解析は, 測定した反射スペクトルから得られる反 射光の各波長に対する反射率のデー夕群を統計解析する 手法である。Fig. 3 は, 鉛白・亜鉛華・チタン白の各色 材を含む白色油絵具の反射スペクトルを判別分析という 手法により多変量解析した結果である。グラフ上の破線 で囲んだ領域に 3 種の色材が相互に判別された。これら の色材を含む白色油絵具は同じ色相のため類似の反射久 ペクトル形状を示すが，多変量解析によって概称良好な 判別結果が得られている。

最近では, ハイパースペクトルカメラが油彩画の科学 調查へ応用されている ${ }^{14)}$ 。ハイパースペクトルカメラ は波長ごとに二次元画像を撮影し，この画像上の任意の 点の反射スペクトルを得る。前述の光ファイバーの付い た分光光度計では一度に一測定点の反射スペクトルしか 測ることができないが，ハイパースペクトルカメラでは 油彩画全体の反射スペクトルを一度の撮影で測定でき る。油彩画の反射スペクトルを測定してX 線分析の結 果と照合し解析すれば, 絵画面上に㧈ける色材のマッピ ング分析が可能になる。さらには，ハイパースペクトル カメラを用いて赤外線領域の反射スペクトルを測定すれ ば，下層に描かれた描写も調査できるようになる。

以上のように反射スペクトル分析は油彩画の科学調查 に利用されている。しかし，実際の分析では幾つか気を 付けなければならないこともある。例えば，油絵具は必 ずしも単一色材で調製されて扔らず, 複数種の色材で調 製されていることもある。単一色材で調製されていても, 混色されていれば測定点には複数種の色材が存在するた め, これらの色材の特性が反射スペクトルに反映され る。そして, 油絵具を組成する乾性油や絵画表面に塗布 されたワニスが変色していれば，これらも反射スペクト ルに影響を与える。さらに, 赤外線は表面の絵具層を透 
過しやすく, 絵具層が薄ければ紫外線や可視光線でも透 過するため，下層の影響を受けることもある。以上のこ とを踏まえて油絵具の反射スペクトルを測定しデータを 解析する必要がある。

\section{4 おわりに}

本稿では，油彩画の科学調査に用いられる写真撮影や 分光分析の主な技術について記した。これらの技術に よって油彩画の科学調査は非破壊かつ非接触で行なわれ ている。しかし，試料を非破壊・非接触で測定すること から，試料を消費し測定を行なう一般的な科学分析に比 ベて制約も生じやすく，油彩画に使用されるすべての材 料を分析でき，あらゆる状態を観察できているとは言え ない。このため, 油彩画の科学調査技術の一層の発展を 目指し，新しい分析法や測定データの解析法なども開発 されている。

以上述べてきた油彩画の科学調査を行なうには，科学 分析の専門性のみならず作品や画家の来歴・修復歴・修 復方法・材料・技法・美術史などに関する専門性も要す る。このため科学調査は, 科学分析の専門家に加え美術 館・博物館の学芸員, 保存修復・絵画技法・美術の専門 家や画家など様々な立場から相互に協力して行われてい る。

\section{文 献}

1）R. J. ゲッテンス， G. L. スタウト，新装版 絵画材料事 典 初版, 森田恒之訳, 美術出版社（1999）。（R. J. Gettens, G. L. Stout, Painting Materials: A Short Encyclopedia, Dover Publications (1999))

2）ホルベイン工業, 絵具材料ハンドブック, 中央公論美 術出版（1991）。（HOLBEIN WORKS, LTD., Handbook of Painting Materials, Chuokoronbijutsu Co. Ltd., Tokyo (1991)
3）ホルベイン工業技術部編, 絵具の科学 改訂新版, 中央 公論美術出版 (2018). (HOLBEIN WORKS, LTD. Research and Development Section, Science of paints. New ed., Chuokoronbijutsu Co. Ltd., Tokyo (2018))

4）山崎一雄, 分析化学, 16, 1099-1103 (1967). (K. Yamazaki, Bunsekikagaku 16, 1099-1103 (1967))

5）馬淵久夫, 杉下龍一郎, 三輪嘉六, 沢田正昭, 三浦定 俊編, 文化財科学の事典 初版, 朝倉書店 (2003)。（H. Mabuchi et al., Science of Cultural Properties: Encyclopedia, Asakura Publishing Co., Ltd. (2003))

6) 早川泰弘, 高妻洋成, 文化財分析 初版, 日本分析化学 会編, 共立出版 (2018). (Y. Hayakawa et al., Analysis of Cultural Properties, Kyoritsu Shuppan Co., LTD. (2018))

7）ひろしま美術館, 吉備国際大学, ゴッホ《ドービニー の庭》のすべて (2008). (Hiroshima Museum of Art, Kibi International University, Vincent van GOGH 'Le Jardin de Daubigny' (2008))

8）ウッドワン美術館, 吉備国際大学，ファン・ゴッホ《農 婦》調查研究プロジェクト（2012）（WOODONE MUSEUM OF ART, Kibi International University, Vincent van GOGH 'Paysanne’ (2012))

9) 中井泉編, 蛍光 X 線分析の実際 第 2 版, 日本分析化学 会 X 線分析研究懇談会監修, 朝倉書店 (2016)。（(I. Nakai, Practical X-ray Fluorescent Analysis. $2^{\text {nd }}$ ed., Asakura Publishing Co., LTD. (2016))

10) K. Nakano, A. Tabe, S. Shimoyama, K. Tsuji, Microchem. J. 126, 496-500 (2016).

11) J. Dik, K. Janssens, G. Van Der Snickt, L. Van Der Loeff, K. Rickers, M. Cotte, Anal. Chem. 80, 6436-6442 (2008).

12) 吉田直人, 保存科学, 50, 207-215 (2011). (N. Yoshida, Science for Conservation 50, 207-215 (2011))

13）大下浩司, 津崎みぎは, 文化財情報学研究, 14, 43-51 (2017). (K. Oshita, M. Tsuzaki, Bunkazai Johogaku Kenkyu 14, 43-51 (2017))

14) J. Striova, C. Ruberto, M. Barucci, J. Blažek, D. Kunzelman, A. Dal Fovo, E. Pampaloni, R. Fontana, Angew. Chem. Int. Ed. 57, 7408-7412 (2018). 